Published in: Environment and Planning C: Government and Policy 2015, volume XX, pages 1 - 22 doi: 10.1177/0263774X15614691. This copy is the final pre-published postpeer-review copy, authorized to share by publisher

\title{
Social networks and regional economic development: The Los Angeles and Bay Area metropolitan regions, 1980-2010
}

\author{
Naji P Makarem \\ Course co-director Msc. Urban Economic Development, Lecturer Political Economy of \\ Development, Bartlett School of Planning, UCL, Development Planning Unit, e-mail: \\ n.makarem@ucl.ac.uk
}

\begin{abstract}
Social capital is widely recognized as an important aspect of regional economies, and social networks in particular have recently been the focus of research in economic sociology and economic geography. Building on this body of work, this research explores the role of social networks in the divergent economic fortunes of two highly advance Californian metropolitan regions over the past three decades, Los Angeles and the Bay Area. Proxies for the two regions' industrial social structures are constructed and analysed at three cross sections over the divergence period: 1982, 1995 and 2010. Network analysis shows that the Bay Area's industrial social structure maintains a high level of connectivity, bridging relations across industrial boundaries, and by 2010 has a highly connected and central business-civic organization, the Bay Area Council. The LA region's social structure, on the other hand, fragments substantially over the period.
\end{abstract}

Keywords: Innovation, social capital, institutions, networks, transposition, entrepreneurship, restructuring, resilience, regional development, industrial evolution, technological frontier, Bay Area, Silicon Valley, Southern California, Los Angeles

"If I've learned anything in the last seven years, it's that ideas live less in the minds of individuals than in the interaction of communities" (Fred Turner, 2006: VII).

\section{Introduction}

Institutions and social capital have risen to the forefront of academic and policy attention as important aspects of economic development. While initial factor endowments capture the static combination of building blocks in an economy, institutional and sociological perspectives attempt to understand how these factors are combined and recombined in a socially interactive and dynamic process of economic and industrial development. Two comparably endowed economies can take different industrial pathways in part due to their distinct formal and informal institutional contexts (laws, norms, beliefs and relations), which in turn impact industrial development and per capita incomes, arguably evident by persistently high residuals in income-growth regressions (Rodríguez-Pose, 2013).

High-end entrepreneurship, intra-preneurship and innovation steer the industrial trajectory of regions as it branches out into new industrial categories and sub-categories. This process is driven by economic actors responding to perceived challenges and opportunities by combining 
and re-combining resources, people and organizations in pursuit of new lucrative opportunities. Economic sociologists and geographers have identified three network features characteristic of highly entrepreneurial firms, small resilient cities and innovative industrial clusters: connectivity, diversity and centrality. These structural features facilitate the flow of knowledge and novel ideas and the forging of new connections in pursuit of innovative and lucrative commercial endeavours.

The research that follows broadens the scope of analysis of past research to the corporate social structures of two highly advanced US metropolitan regions whose per capita incomes diverged substantially since the early 1980s: The Bay Area and Los Angeles metropolitan regions. The Bay Area is the quintessential poster child of high-end entrepreneurship and innovation, while the Los Angeles region has been much less innovative over the past three decades. Network analysis shows that over the 30 years of economic divergence the structure of relations in the two regions' high-end corporate social networks also diverged substantially. Moreover, the network features found to characterize highly entrepreneurial communities, resilient cities and innovative clusters are characteristic of the Bay Area's high-end corporate social network throughout the period: connectivity, diversity and centrality of an 'anchor tenant'. These are precisely the features theorized as facilitating the combination and recombination of assets, people and organizations in response to perceived challenges and opportunities.

This article begins with a literature review of the role of social capital and social networks in economic outcomes, followed by the methodology section explaining the rationale behind chosen proxies for the two regions' social contexts and sampling frame. We then present the results of our network analysis and conclude. 'The most crucial aspect of Silicon Valley is its networks'. There is no proposition so universally agreed upon and so little studied (Castilla et al., 2000: 218).

\section{Institutions and economic development: A literature review}

The social capital literature is based on the notion that certain features of society such as norms, trust, identities and membership determine the propensity for cooperation between agents (Fukuyama, 1999). Putnam defines social capital as 'features of social organization, such as networks, norms and trust that facilitate coordination and cooperation for mutual benefit' (Putnam and Leonardi, 1993: 38).

Social scientists, namely urban focused economists, economic geographers and economic sociologists, have studied the role of social capital (Bourdieu, 1986; Coleman, 1988; North, 1981, 1990, 2005; Putnam, 2000) and social networks (Owen-Smith and Powell, 2008; Glaeser et al., 1995; Granovetter, 1985; Jaffe et al., 1993; Powell et al., 2012; Saxenian, 1996) in regional economies and industrial structures. Social capital and the structure of social networks in which it is embedded influence how actors in an economy interact. While formal institutions to a great extent determine the 'rules of the game in a society' (North, 1990: 3), the 'humanelydevised constraints that shape human interactions' (North, 1990: 3) are also shaped by important aspects of society, such as networks, trust, norms and ideology. Different conventions and relations in urban centres can generate differences in the way people from across various organizations interact and respond to collective challenges and opportunities (Storper, 1997).

Social capital and social networks have arguably become increasingly important in economic development in the post-Fordist economy as labour markets have become more 
flexible, production more fragmented and vertically disintegrated and competition more intensive (Scott, 1988; Storper, 1992). Social capital can increase the efficiency and flexibility of the labour market (Granovetter, 1985, 2005); lower transactions costs by generating trust between agents (Bowles and Gintis, 2002; Fukuyama, 1999; Putnam, 2000), limiting moral hazards (Putnam, 2000) and reducing the reliance on formal contractual agreements (Rodriguez-Pose and Storper, 2006; Storper, 1997); and facilitate knowledge creation and spillover (Cohen and Levinthal, 1990; Easterly, 2001; Granovetter, 1985; Wade, 1987). The latter in particular plays a crucial role in agglomeration economies and long-run economic growth, as emphasized by contemporary growth theory (Aghion and Howitt, 1992; Grossman and Helpman, 1991; Jones, 2004; Lucas, 1988; Romer, 1986, 1987, 1990, 1993). These positive aspects of informal institutions correspond with the three widely recognized agglomeration economies of 'matching', 'sharing' and 'learning' (Duranton and Puga, 2004; Marshall, 1890). Informal institutions are thus theorized as being integral to processes of agglomeration and innovation, and consequently regional economic development.

The link between propinquity (which reduces the transactions costs between agents facilitating the development of social capital) and 'learning' is substantiated by so-called paper-trail studies (Jaffe and Tranjtenberg, 1999, 1998; Jaffe et al., 1993; Sonn and Storper, 2008), and research using other proxy measures of innovation inputs, such as R\&D spending (Jaffe, 1986; Patel and Pavitt, 1991), and innovation output, namely new product developments (Feldman, 1994). In a literature review of this body of research, Feldman concludes that 'knowledge spillovers tend to be geographically bounded within the region where new economic knowledge was created. That is, there are geographic limitations to the spillovers of new economic knowledge' (Feldman, 1999: 4). Knowledge diffuses unevenly across space because it is more easily absorbed by actors connected to the social structure in which it is developed (Cohen and Levinthal, 1990). These social connections require frequent face-to-face contact due to the tacit nature of knowledge, thus benefiting from propinquity.

Propinquity between agents in geographic space, however, does not insure interaction; it simply reduces the physical distance between agents and consequently transaction cost, facilitating interaction. Interaction is further facilitated by social relations between agents. In this sense, studies of the role of networks and social capital in economic development are essentially sociological studies of agglomeration and transactions costs. The 'social distance' between agents in two equally populated and dense cities (i.e. between equally distanced agents) can be markedly different, depending on the social structure or 'conventions and relations' that connect these agents (Storper, 1997). Economic geographers and economic sociologists essentially study two inter-related dimensions of agglomeration economies, geography and social relations, both of which determine transactions costs.

Closely knit clusters and communities, however, can have negative effects on economic outcomes due to the agency problems that they generate (Buchanan and Tullock, 1962; North, 1981; Olson, 1965), especially in contexts of weak formal institutions (Rodriguez-Pose and Storper, 2006). Research shows, for example, that the overall development of southern Italy has suffered from negative externalities associated with the dominance of closely knit clientilistic and rent-seeking groups (Triglia, 1992). Moreover, such group 'bonding' with little inter-group 'bridging' can bring about deep social divisions that can limit an economy's overall growth potential (Aghion et al., 2004; Easterly and Levine, 1997). Rodrigues-pose and Storper argue that group 'bonding' must be balanced with the 'bridging' mechanisms of formal institutions in order to avoid such negative externalities (Rodriguez- Pose and Storper, 2006). 
Cross-cutting social relations are arguably an additional 'bridging' mechanism that can also limit the negative externalities of strong community 'bonding' (Makarem, 2013).

The link between social networks and economic outcomes can be traced back to Alfred Marshall's (1890) observations about the development and diffusion of ideas in English industrial districts. Since then social scientists from different fields such as regional science, economic geography and economic sociology have sought to better understand the role of social networks in regional economies. Granovetter argued in his seminal work on the social embeddedness of economic activities drew attention to the importance of what he called 'weakties in the transmission of novel ideas and information between close-knit communities ties' (Granovetter, 1985). Jane Jacobs attributed the economic and entrepreneurial dynamism in cities to the diversity and ease of social interactions in dense urban centres (Jacobs, 1969). Research on Silicon Valley attributed the region's entrepreneurial dynamism to its dense networks and culture (Kenney and Florida, 2000; Kenney and von Burg, 2001; Saxenian, 1983, 1990, 1996; Sturgeon, 2000), findings echoed in research on industrial districts in Europe (Bagnasco, 1977; Brusco, 1986; Cooke and Morgan, 1994; Kristensen, 1992; Piore and Sabel, 1984; Storper and Harrison, 1991; Triglia, 1992). Saxenian argues that 'The network perspective helps explain the divergent performance of apparently comparable regional clusters' (Saxenian, 2001: 42).

Researchers adopted social network analysis techniques to gain a more in-depth understanding of the role of networks in regional economic outcomes. Safford showed that the structure of civic relations shaped the trajectories of economic change in two rust-belt cities, enabling one to better respond collectively to economic challenges than the other. He attributed successful collective action and mobilization of key organizational actors in response to the city's economic challenges to interactions between actors from across social, political and economic divisions, highlighting the role of centrally positioned civic organizations in the development and coordination of strategic initiatives (Safford, 2004).

Powell and his colleagues found that highly successful biotechnology clusters are characterized by diverse and connected organizational forms. The diversity he argues 'provides a rich soup in which practices, strategies and rules can emerge' from a process which 'involves search, recombining, sense-making, and luck' (Powell, 2010: 12). He also highlights the important connecting role played by an 'anchor tenant', an organization that does not compete directly with other types of organizations but rather 'becomes scaffolding that, either intentionally or unexpectedly, assists subsequent connections and field formation' (Powell, 2010: 13). Well-connected actors from diverse business communities thus catalysed the entrepreneurial dynamism that led to the genesis of highly successful biotechnology clusters (Powell et al., 2012a, 2012b, Powell and Sandholtz, 2012; Powell et al., 2005).

Feldman and Zoller also used network analysis to show that highly entrepreneurial regions are characterized by a disproportionate number of 'dealmakers' (Feldman and Zoller, 2012). These serial entrepreneurs bring together actors from distinct fields on the corporate boards of new ventures. They 'assume roles that make the connections from which knowledge spills over to lower the costs of engaging in innovative activity, thus creating regional vibrancy' (Feldman and Zoller, 2012: 3). Their research builds on a body of research highlighting the catalytic role played by centrally positioned information brokers that connect actors from distinct communities (Myint et al., 2005; Pollock et al., 2004; Suchman, 2000; Winch and Courtney, 2007). 
Cutting across these studies is the notion that social contexts whose actors are more diverse and connected, all else being equal, are more creative, innovative and able to forge new relations in the face of collective economic challenges and opportunities. The above-reviewed research, however, falls-short of exploring this theoretical proposition at the scale of large metropolitan regions; the subsequent research attempts to fill this gap by broadening the scope of analysis to the corporate social structures of two metropolitan regions in the State of California.

\section{Case selection}

The 10 County Bay Area1 and 5 County Los Angeles 2 metropolitan regions are two highly advanced regions in the State of California which had successfully grown their populations, employment base and wages over the course of the 20th-century. They are both subject to the same state and federal systems of government, thus controlling for major differences in formal institutions, 3 openness to international trade, capital controls, immigration laws and macroeconomic conditions.

By 1980, they were both in the top-tier of the US regional income hierarchy, with very similar levels of per capita incomes, income inequality, housing costs and construction restrictiveness (Makarem, 2013; Storper et al., 2015). Their industrial structures were also comparable, with similar shares of employment in IT, similar sophistication in their occupational task contents and similar patents per capita (Makarem, 2013; Storper et al., 2015). Over the course of the subsequent three decades, however, the two regions diverged substantially in their per capita incomes. By 2010, the average Los Angeles resident earned almost 30\% less than the average Bay Area resident, and the Los Angeles region had slipped down the rankings of US regional incomes from 9th place back in 1980 to 26th place in 20104 (see Table 1).

While the Bay Area's economic success is attributed to its specialization in the IT sector, this view is retrospective. Back in 1970, the employment share of IT workers in the Bay Area and the Los Angeles region was almost identical at 2.6\%, which in light of LA's relative size meant twice as many Information Technology (IT) workers in LA (almost 82,000 in LA versus just below 39,000 in the Bay Area as shown in Table 2). By 2010, however, the Bay Area's share of IT employment rose to nearly $11 \%$, larger than LA's in both relative and absolute terms (255,000 in the Bay Area compared to just over 150,000 in LA). An economic observer back in the 1970s and early 1980s might have favoured the prospects of LA based on the region's human capital in the IT industry, the large number of aerospace engineers which back in 1970 was even larger than its stock of IT workers, and its leading agglomeration in the entertainment industry (see Table 2).

Table 1. Per capita incomes in the LA and Bay Area CMSAs, 1980 and 2010.

\begin{tabular}{lcccc}
\hline $\begin{array}{l}\text { Per capita income } \\
\text { (ii=53 regions with 2010 pop }>1 M)\end{array}$ & 1980 & Rank-1980 & 2010 & Rank-2010 \\
\hline San Francisco-Oakland-San Jose, CA (C) & $\$ 9,312$ & 1 st & $\$ 37,974$ & 1 st \\
Los AngeLes-Riverside-Orange County, CA (C) & $\$ 8,360$ & 9 th & $\$ 27,525$ & 26th \\
Difference between SF and LA pci & $\$ 952$ & & $\$ 10,449$ & \\
LA percentage share of SF pci (LA/SF) & $90 \%$ & & $72 \%$ & \\
\hline
\end{tabular}

Source: Author's calculations using BRR15 data. 
While the Bay Area's economic success is attributed to its specialization in the IT sector, this view is retrospective. Back in 1970, the employment share of IT workers in the Bay Area and the Los Angeles region was almost identical at 2.6\%, which in light of LA's relative size meant twice as many Information Technology (IT) workers in LA (almost 82,000 in LA versus just below 39,000 in the Bay Area as shown in Table 2). By 2010, however, the Bay Area's share of IT employment rose to nearly $11 \%$, larger than LA's in both relative and absolute terms (255,000 in the Bay Area compared to just over 150,000 in LA). An economic observer back in the 1970s and early 1980s might have favoured the prospects of LA based on the region's human capital in the IT industry, the large number of aerospace engineers which back in 1970 was even larger than its stock of IT workers, and its leading agglomeration in the entertainment industry (see Table 2).

Table 2. Number and share of IT and aerospace \& defense industry workers in LA and the Bay Area, 1970-2010.

\begin{tabular}{lcccc}
\hline Year & \multicolumn{2}{c}{ Los Angeles } & \multicolumn{2}{c}{ Bay Area } \\
\hline \multirow{2}{*}{1970} & IT workers & Share & IT workers & Share \\
2010 & 81,872 & $2.6 \%$ & 38,621 & $2.7 \%$ \\
& 153,524 & $2.7 \%$ & 255,334 & $10.2 \%$ \\
& Aerospace \& defense & Share & Aerospace \& defense & Share \\
1970 & workers & & workers & \\
2010 & 108,083 & $3.4 \%$ & 455 & $0.03 \%$ \\
& 47,960 & $0.9 \%$ & 735 & $0.02 \%$ \\
1970 & Entertainment workers & Share & Entertainment workers & Share \\
2010 & 22,978 & $0.7 \%$ & 2,171 & $0.15 \%$ \\
\hline
\end{tabular}

Source: Calculations by Tom Kemeny based on collections of 4-digit SIC codes (1970) and 6-digit NAICS codes (2010) using County Business Patterns (Storper et al., 2015).

Why did these two advanced US metropolitan regions in the same State of California respond so differently to the challenges of the new economy? Economists would point to differences in initial factor endowments.

A regression analysis predicting 2010 per capita incomes for US metropolitan regions controlling for major determinants of income-growth back in 1980 (and a second model controlling for changes in some variables over time) shows that the Bay Area's actual 2010 income was $22 \%$ above its expected value, whereas LA's was $7 \%$ below its expected value (Makarem, 2013). The analysis controlled for population size (and growth in a second model), cost of housing, measures of human capital, ethnic composition (and change in a second model), industrial structure and levels of innovation (see descriptive statistics of control variables in Appendix 1). Numerous specifications yielded comparable results presented in Appendix 2. The analysis shows that neither the spectacular income growth of the Bay Area nor the lackluster income growth of the LA region can be satisfactorily explained by initial factor endowments. 
The disappointing performance of the LA region is often attributed to the decline of the aerospace sector, which is blamed on political decisions in Washington in the late 1980s that reassigned military contracts to other regions (Thomas and Ong, 2002). While the decline of the aerospace sector took a heavy toll on employment, shrinking from $3.4 \%$ of regional employment in 1970 to $0.9 \%$ in 2010 (see Table 2), this does not explain why the region was unable to grow its employment in high-waged sectors of the new economy, such as IT and biotechnology. Moreover, while its entertainment industry is a hugely successful story, having grown from $0.7 \%$ of regional employment in 1970 to $2.5 \%$ in 2010 , its size relative to the regional economy is insufficient for maintaining the region's per capita income relative to other regions.

LA's failure to sufficiently exploit commercial and technological opportunities in the new economy is striking given the region's promising position in the early days of the biotech industry (see Powell et al., 2012a), its wealth of highly skilled technology workers in the aerospace industry (Taner Osman's case study of the aerospace and defence industry in Storper et al., 2015), its global dominance in the entertainment industry (with its branching-out potential into related high-waged sectors such as animation, digital content creation, video games and high-fashion design) (Makarem, 2013; Storper et al., 2015), and a 2.7\% share of IT workers in 1970, equivalent to that of the Bay Area and double its size in absolute terms (see IT case study by Taner Osman and analysis of industrial composition by Tom Kemeny, in Storper et al., 2015).

The Bay Area's relatively high income growth was, to a great extent, driven by highly innovative activities and entrepreneurial ventures in the IT industry. Figure 1 shows the divergence in the number of patents granted to each region between 1975 and 2005 in two IT sub-sectors, computers and communications, and electrical and electronics (data analysed by Tom Kemeny and presented in Storper et al., 2015). The two regions' innovation capacities in these two IT sub-sectors diverged tremendously since the early 1990s. This divergence in innovation capacity is also evident in the overall level of patents filed: by 2010, the total number of patents per capita in LA was 36, compared to 48 in the Bay Area (Makarem, 2013, using Building Resilient Regions (BRR) data). The period of economic divergence coincided with a divergence in the two regions' industrial structures and innovation capacities.

As initial factor endowments cannot sufficiently explain the evolution of these two metroregions' per capita incomes, innovation capacities and industrial structures, 5 it is plausible that differences in the two regions' social structures played a role in their divergence. Back in 1980, the LA region seemed poised to exploit the opportunities of the new economy by innovating and branching out into high-skilled and innovative sectors of the new economy. The region's economic story, however, did not unfold as one might have expected. While the Bay Area over-performed relative to US regions with comparable initial factor endowments, LA's under-performed. The research that follows explores the role the two regions' industrial social structures might have played in their economic divergence. 

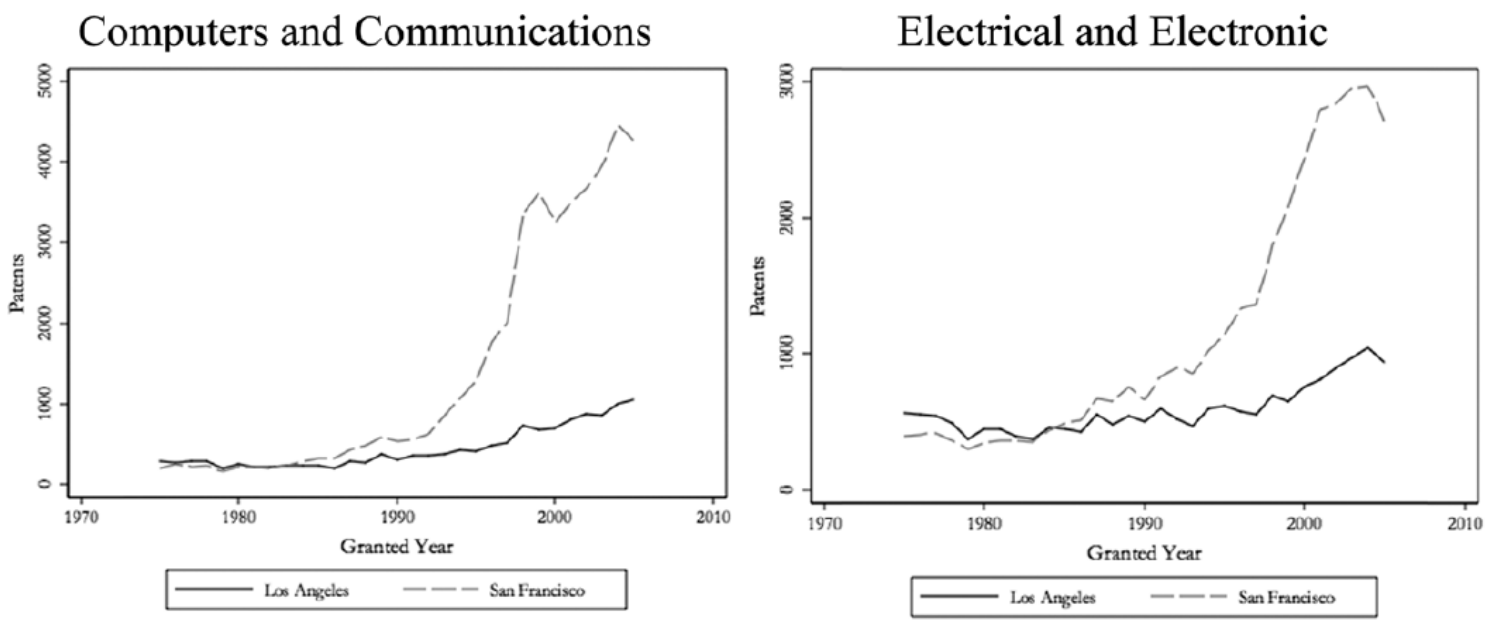

Figure 1. USPTO utility patents granted by region, 1975-2005.

Source: Calculations by Tom Kemeny based on NBER patent data, as cleaned and organized in Sonn and Storper, 2008 (Storper et al. 2015).

\section{Methodology}

Economic actors are embedded in a structure of social relations which span regional and extraregional social networks. The challenge of measuring the regional social structure in which economic actors are embedded is operationalized by restricting the analysis to directors who sit on the boards of the largest corporations and private foundations in the two regions. Social relations between these board members is proxied by board interlocks: If a director sits on the boards of two organizations, then the board members of these two organizations are considered to be socially related (they are acquainted).

In theory, corporate board members constitute economic actors whose network of interlocked boards forms 'a social institution' (Davis, 1996: 1) which acts as a 'communication system' (Mintz and Schwartz, 1985: 141) whose membership is selected through personal ties (Mizruchi, 1996), with the overall network reflecting 'the embeddedness of corporate governance in social structures (e.g. friendship or other ties)' (Davis, 1996: 1). Private foundations are also included in the analysis because corporate directors often sit on the boards of private foundations, and therefore including private foundations in the analysis incorporates an important channel of social connections. The network of corporate and philanthropic board interlocks is therefore an appropriate proxy for gauging 'who knows whom' and 'who has direct and indirect but proximate access to whom' amongst actors in a region's industrial structure.

The sample of firms is restricted to the largest 60-70 corporations and 50 largest private foundations in each region in 1982, 1995 and 2010. Research shows that larger firms have a higher propensity to share board members with other firms, and moreover that these firms are more likely to be other large firms (Allen, 1974; Dooley, 1969; Levine, 1977; Mizruchi and Stearns, 1988). Selecting a sample of the largest firms rather than a random sample of firms from across the industrial structure, therefore, minimizes the risk of selection bias (unequal propensity to interlock) and selects the pool of firms with the most number of board interlocks (the proxy for social relations). 
As well as exploring the overall structure of board interlocks amongst the largest firms, the analysis also explores the degree to which these relations connect firms across industrial boundaries. Board interlocks across industries are used as a proxy for relations between diverse communities within the overall industrial structure, i.e. diversity.

The structure of relations amongst the most influential business and philanthropic leaders in a region is arguably representative of a much broader social structure ('a friend of yours is a friend of mine'). If for instance the corporate board of an aerospace company is interlocked with the board of an IT company, it is likely that other actors from these two industries' social worlds are also connected, either directly or indirectly through this 'weak tie'.

In addition to exploring the structure of relations across the two regions' industrial structures by measuring the degree of overall connectivity and bridging relations across industries, the analysis adds the five most prominent business-civic organizations (BCOs) to the networks in 2010.6 The purpose of BCOs such as chambers of commerce and business associations is to act as convening bodies for the business community. Their primary objective or 'raison-d'être' is to represent the needs and interests of the business community. It is conceivable, therefore, that such organizations, through their board interlocks, connect otherwise disconnected corporations in the above networks, acting as 'anchor tenants' in the overall network.

A total of 386 corporations and 4130 board members were analysed, equivalent to an average of 64 corporations and 688 board members per region for each of the three cross sections (1982, 1995 and 2010). The average number of board members per firm was 11, consistent with findings in the broader directorate interlock literature (Hallock, 1997).

Firms were ranked by total revenues using Dunn's Business Rankings7 publication for the 1982 sample, the Wharton Research data Service and the 1995 Dunn's Business Rankings for the 1995 samples and the Dunn and Brad Street 2010 Million Dollar Directory and Morningstar Inc. (10K Wizard database) for the 2010 samples. The directors' names were extracted from the list of board members found in the corporate 10-Ks (the tax documents filed by the Internal Revenue Service (IRS)), or firms' annual reports. The 10Ks of firms in the 1982 sample were accessed from archives held at the Jackson library at Stanford University. The 1995 and 2010 10-Ks were accessed online from the Edgar database (available free online from the Securities and Exchange Commission). The sample sizes for each cross section were 70 firms in 1982, 60 in 1995 and 63 in 2010. The sample sizes differ slightly due to data availability.

Private foundations were ranked by total assets by accessing data from the foundation directory 9th edition for the 1982 sample, and the National Centre for Charitable Statistics (NCCS) online databases for the 1995 and 2010 samples. The names of trustees were extracted from the 990 forms submitted by private foundations to the IRS for reporting purposes. They were accessed from Indiana University Perdue University Indianapolis Library Archives for the 1982 and 1995 samples, and from the NCCS online archive for the 2010 samples.

The database of director and trustee names was 'cleaned' by insuring identical spelling, and names whose spellings differed were matched through a combination of consistent rules and internet searches to insure that, for example, John D Smith is the same person as John Dereck Smith. 8

The five most prominent business-civic organizations (BCOs) in each region were selected by following a two-stage sampling method: In the first stage, a snowball strategy was used, 
whereby academics and practitioners in business and civic communities were asked to name the most prominent BCOs in their regions. In the second stage, organizations identified in stage one were ranked by their exposure in newspapers, by ranking them by media hits using NexisLexis, and selecting the top five most cited organizations.

\section{Findings}

\section{Corporate networks}

The corporate board networks in the two regions were very similar back in 1982 and were both highly connected with around $60 \%$ of firms connected to at least one other firm, and around $55 \%$ of firms connected to each other in the largest component 9 in both regions.

By 2010, the Bay Area corporate network had maintained its high number of board interlocks, with $78 \%$ of firms connected to at least one other firm and $57 \%$ of firms connected to each other in its largest component. In the LA region, on the other hand, the corporate network by 2010 had fragmented significantly over the period, with $41 \%$ of firms connected to at least one other firm, and more tellingly, only $19 \%$ connected to each other in the largest component (as illustrated in Figure 2). There was a large decline in the size of LA's largest component between 1995 and 2010.

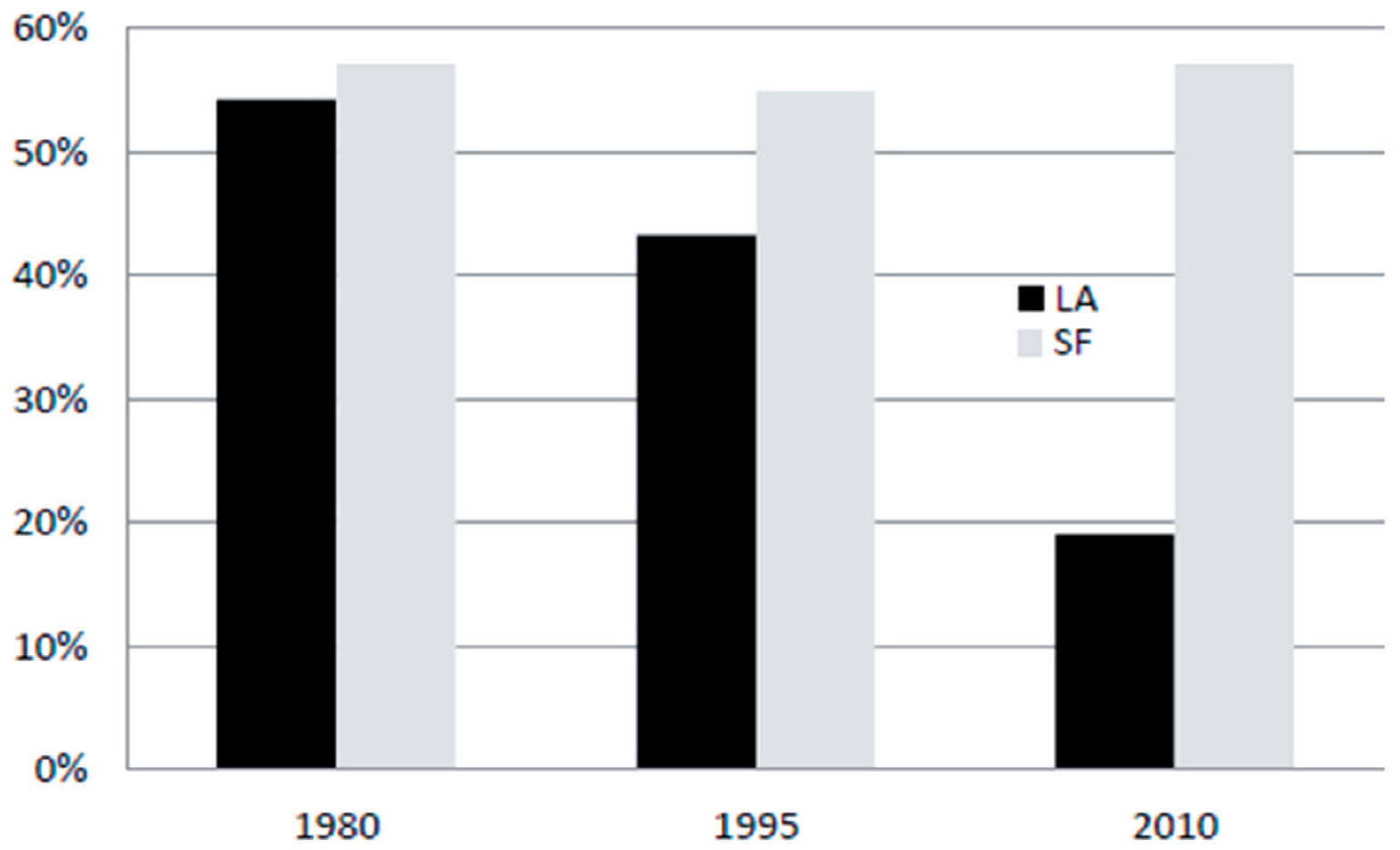

Figure 2. Percentage of sampled firms in largest component, by year, LA vs. SF. Source: Author's calculation, number of interlocked firms in each network's largest component as a percentage of all firms in the sample 
Figures 3(a) and (b) show graphic representations of the two regions' sampled corporate networks in 1982 and 2010. Figure 3(a) shows a graphical representation of the LA and Bay Area networks in 1982; they are very similar, with 38 firms in LA's largest component, and 42 in the Bay Area's. The two regions' most connected firms are their largest banks and utility companies: Security Pacific Corp and Southern California Edison in Southern California; and Wells Fargo and Pacific Gas and Electric in the Bay Area, each connected to about 11 other firms.

By 2010, as illustrated in Figure 3(b), the LA network has all but completely fragmented, with a mere 12 firms in the largest component, compared to 36 in the Bay Area's. Avery Denison in Southern California is the most connected firm in the region's sampled firms, connected to just four other firms, compared to Intuit in the Bay Area with connections to seven other firms, and Intel and Cisco with connections to six other firms each.

(a)
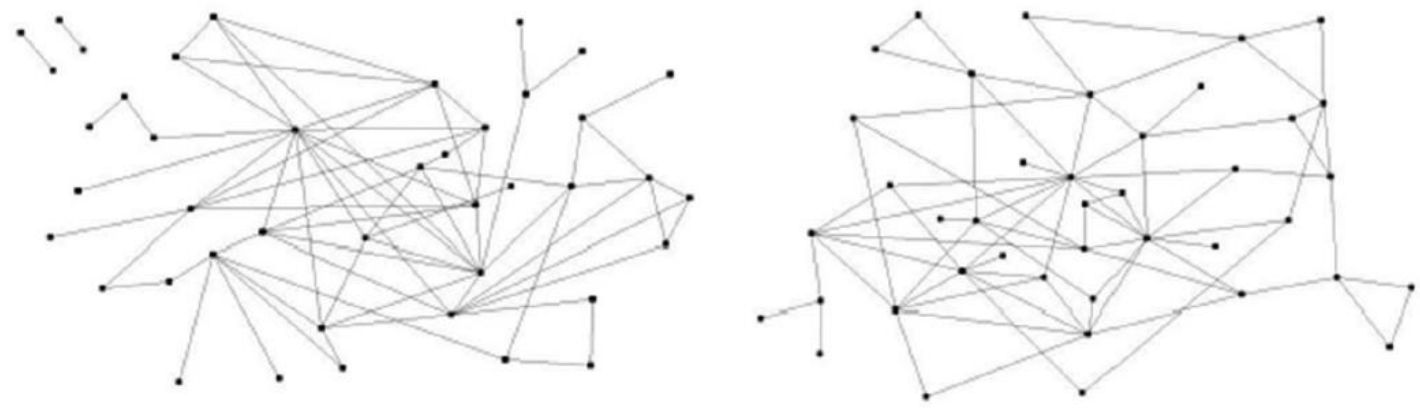

(b)

LA

SF
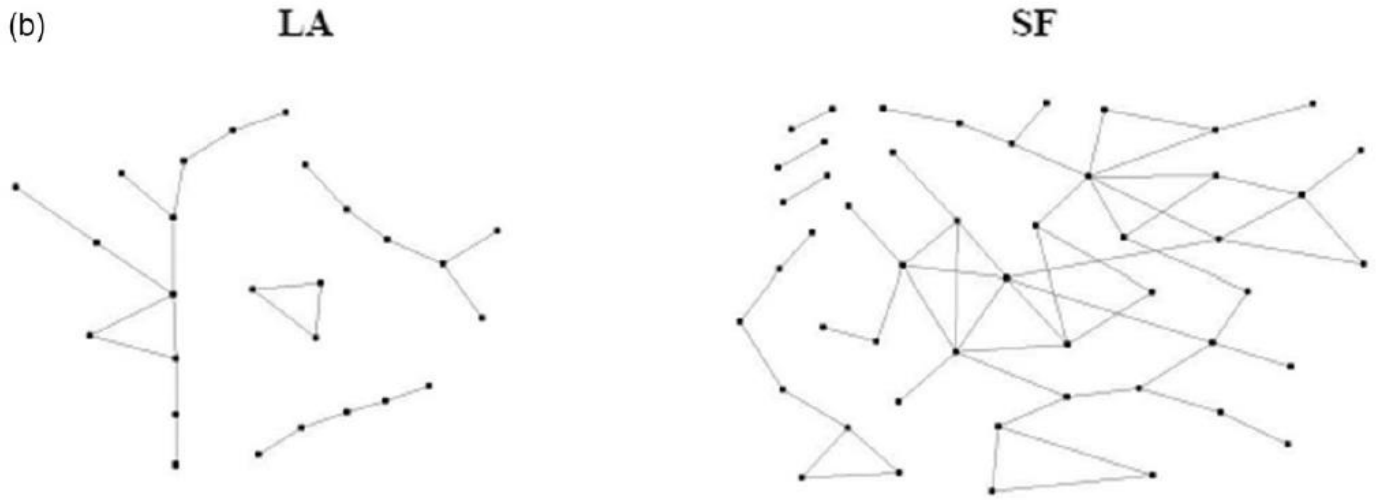

Figure 3. (a) LA and SF networks of board interlocks, 1980 and (b) LA and SF networks of board interlock, 2010.

Source: Author's calculations using UCINET14 and NET-Draw.

This analysis shows the gradual fragmentation in LA's high-end corporate social structure between 1980 and 1995, and the accelerated fragmentation between 1995 and 2010. The Bay Area's corporate network, however, maintains its relatively high level of connectivity throughout the 30-year period. The networks are now broadened to include the 50 largest private foundations. 


\section{Broader corporate-philanthropic networks}

The broader corporate-philanthropic networks generate results consistent with the above exclusively corporate analyses: Both regions had highly connected high-end corporatephilanthropic social structures back in 1982, with about half the organizations - firms and private foundations - in both regions' broader networks connected to at least one other organization (recall the figure back in 1982 for the corporate network was around 60\% in both regions, here with almost double the number of organizations, the percentage is only slightly lower, at 53\% and 51\% in LA and the Bay Area, respectively).

Between 1982 and 1985, the Bay Area network maintained its degree of inter-organizational connectivity, while the LA network by 1995 began to show signs of fragmentation, as illustrated in Figure 4. By 2010, the LA corporate-philanthropic network continued to fragment, whereas SF's network become more connected than in either 1982 or 1995, with $62 \%$ of organizations connected to at least one other organization by 2010 .

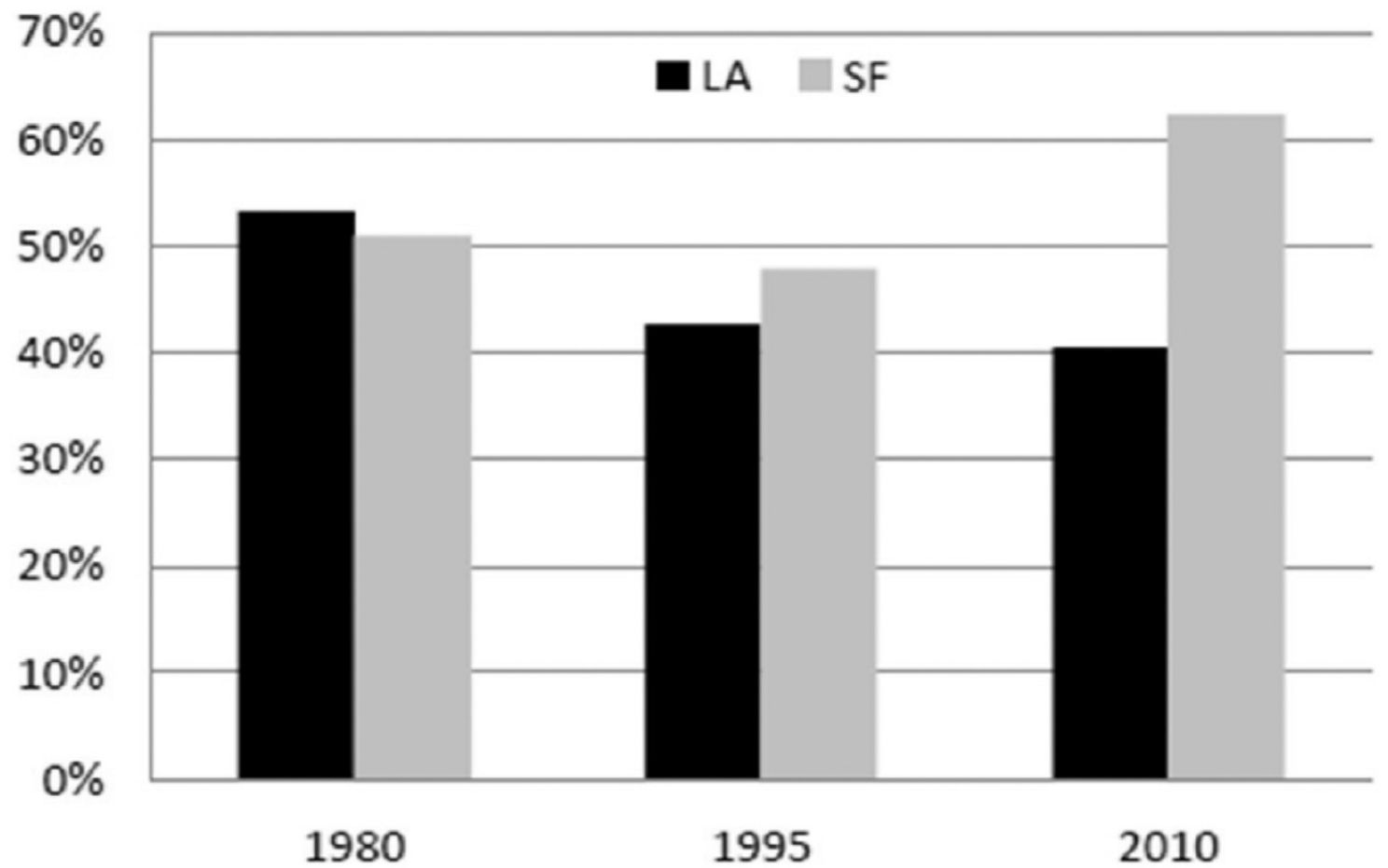

Figure 4. Percentage of organizations connected to at least one other organization in the broader corporate-philanthropic networks in LA and the Bay Area, 1982, 1995 and 2010.

Source: Author's calculations using UCI-NET.

The story holds for the size of the largest components (see Figure 5); both regions' largest components shrank between 1980 and 1995, but while LA continued its downward trend, by 2010 the San Francisco region (SF) reversed this trend and almost re-gained the number of corporations and private foundations it had in its largest component back in 1980. 


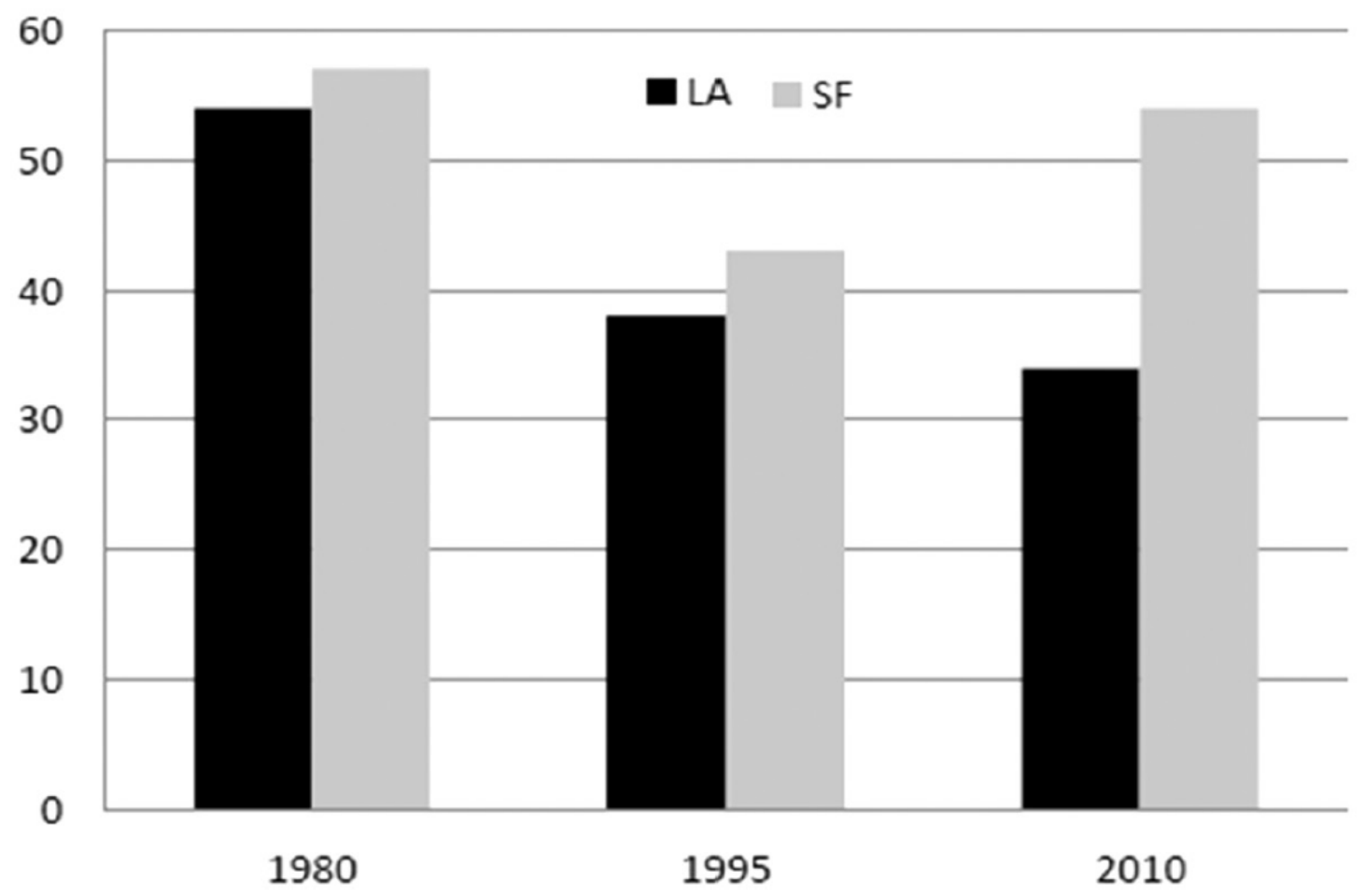

Figure 5. Number of organizations in largest component (Corporate-Philanthropic networks), 1980, 1995 and 2010.

Source: Author's calculations.

Private foundations do not play much of a bridging role in the corporate networks, evident by the few firms added to the combined network. Moreover, the number of private foundations in the combined networks in all cross sections is very similar across the two regions; therefore, their inclusion in a broader corporate-philanthropic network makes virtually no difference to the results from the above strictly corporate network analysis.

Whether the analysis is restricted to the structure of the high-end corporate networks or broadened to the high-end corporate-philanthropic networks, findings are consistent and tell the same story: the Los Angeles and Bay Area corporate and corporate-philanthropic networks were both highly connected back in 1980, a level of connectivity maintained by the Bay Area over the subsequent three decades, in stark contrast to LA's increasingly fragmented network structure. The most prominent and representative BCOs are now added to the 2010 networks to explore their degree of connectivity and centrality.

\section{Centrality of $B C O s$}

In network analysis, the concept of centrality is captured by a measure called 'betweenness centrality', which measures the number of times a node falls on the shortest path between all pairs of nodes in a network.10 The greater the centrality of a $\mathrm{BCO}$, the more it plays a central connecting role in its network, reducing the 'social distance' between nodes. It is helpful to convert this absolute measure into a percentage of all shortest paths for comparison across networks, whereby an 'nBetweeness' score of say $15 \%$ for node A means that node A lies on $15 \%$ of all the shortest paths between all node pairs in the network. 
Network analysis of board interlocks between the corporate-philanthropic networks and the five selected BCOs was conducted for each region in the year 2010. The results, which are presented in Table 3, reveal the Bay Area Council in the Bay Area to be the most central organization in the network, with an nBetweeness score of $18 \%$ (i.e. The Bay Area Council lies on $18 \%$ of the shortest paths between all node pairs in the largest component, within which it is embedded). This is three times greater than the LA Chamber of Commerce, the most central BCO in the LA network, with an nBetweeness score of 5.86\%.

The remaining BCOs in LA have very low centrality scores, with LAEDC lying on fewer than $2 \%$ of all the shortest paths between nodes, less than $1 \%$ for the Valley Industry and Commerce Association, and zero centrality for the Orange County Business Council and CALSTART. In the Bay Area, on the other hand, following the Bay Area Council is the Silicon Valley Leadership group which lies on the shortest path of $6 \%$ of all organization pairs, the San Francisco Chamber of Commerce with a centrality measure of just below $6 \%$ and the SemiConductor Industry Association also with an nBetweeness score of 6\%. Only the JV:SV in the Bay Area does not lie on the shortest path of any two nodes in the network.

Table 3. Degree and betweenness centrality measures of BCOs in the Bay Area and Southern California, 2010.

\begin{tabular}{|c|c|c|c|c|c|c|}
\hline Southern California & 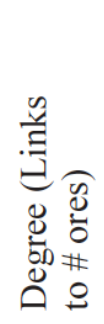 & 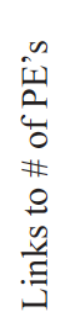 & 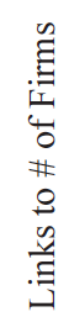 & $\begin{array}{l}E \\
\bar{n} \\
\bar{\sigma} \\
\bar{\sigma} \\
\overline{\bar{n}}\end{array}$ & 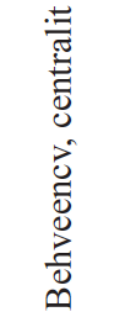 & 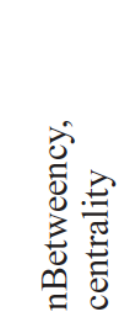 \\
\hline LA Chamber of Commerce & 9 & 4 & 2 & 3 & 405 & $5.86 \%$ \\
\hline LAEDC & 2 & 0 & 1 & 1 & 117 & $1.1 / \%$ \\
\hline $\begin{array}{l}\text { Valley Industry \& Commerce } \\
\text { Association }\end{array}$ & 2 & 0 & 1 & 1 & 41 & $0.59^{\prime}$ \\
\hline OC Business Council & 1 & 0 & 0 & 1 & 0 & $0,00 \%$ \\
\hline CALSTART & 0 & 0 & 0 & 0 & 0 & $0.00 \%$ \\
\hline \multicolumn{7}{|l|}{ Bay Area } \\
\hline Bay Area Council & 12 & 2 & 7 & 3 & 1.244 & $18.02 \%$ \\
\hline SVLO & 6 & 0 & & 1 & 415 & $6.02 \%$ \\
\hline $\begin{array}{l}\text { San Francisco Chamber of } \\
\text { Commerce }\end{array}$ & 3 & 2 & ‘' & $\cdot_{-}$ & 401 & $5.81 \%$ \\
\hline Semiconductor Ind Assoc & $\mathrm{S}$ & 0 & & 0 & 344 & $4.98 \%$ \\
\hline JVSV & - & - &.. $\mathrm{i}$ & - & i. & $0 \%$ \\
\hline
\end{tabular}

Source: Author's calculations using UCINET and NetDraw. 
A closer look at the type of organizations connected to each BCO also reveals noteworthy differences. Almost half of the LA Chambers' connections are to private foundations (4 out of 9), three to other BCOs (the OC Business Council, the Valley Industry and Commerce Association and LAEDC) and only two of the region's sampled largest corporation, Unified Grocers which is not connected to any other firm in the region, and Aecom Technology Corp which is connected to only two other firms. The Bay Area Council, on the other hand, is connected to 12 other organizations, only two more than the LA Chamber, but seven of these board interlocks are with firms in the 2010 sample of corporations (over 10\% of the region's largest firms).

The Bay Area Council arguably plays the role of an 'anchor tenant' within the region's industrial social structure. No comparable BCO exists in LA. The analysis proceeds to explore the degree of bridging cross-industry relations in these regional networks.

\section{Cross-industry relations}

A region's industrial social structure is composed of actors from across its various industries. A diverse industrial social structure would, therefore, include connected actors from different industries in the network. In this section, the diversity of the LA and Bay Area networks are analysed over time, by analyzing the degree to which board interlocks connect corporations in different industries.

Before presenting the results of the analysis, it is important to explore the industrial composition of sampled firms at each cross section, to see whether the results might be biased by the number of industries in each sampled cross section. Consistent with the overall specialization of the Bay Area economy and the diversification of the LA economy over the divergence period, the number of 2-Digit SIC codes representing the sample of firms also diverges over time. The LA and Bay Area samples of firms in 1982 and 1995 are almost identically diverse, representing approximately 30 2-Digit SIC industrial categories in each cross section (see Table 4). Between 1995 and 2010, however, the industrial structures of the two regional samples diverge substantially. By 2010, the Bay Area sample represents $212-$ Digit SIC industrial categories, compared to 36 (greater than in 1982 and 1995 samples) in LA.

Table 4. Number of 2-Digit SIC codes represented by sample firms in the two regions.

\begin{tabular}{lll}
\hline Year & LA & SF \\
\hline 1980 & 32 & 30 \\
1995 & 28 & 27 \\
2010 & 36 & 21 \\
\hline
\end{tabular}

Source: Author's calculations using SIC codes assigned to each firm by the IRS, and recategorized where deemed appropriate.

The analysis also reveals greater concentration of firms in fewer industries in the Bay Area samples over time. For instance in 2010, the three industries with the greatest number of sampled firms represented only 12 of the largest 50 firms in LA, compared to 37 in the Bay 
Area. A greater number of firms is concentrated in a fewer number of industries in the Bay Area sample.

Given the greater degree of industrial specialization and concentration in the Bay Area in 2010, one would expect a random network11 of board interlocks to generate more crossindustry ties in LA than in the Bay Area12 over time. The findings that follow, however, show otherwise.

Several measures are needed to analyse the degree of cross-industry relations. To begin with, two measures are used: the degree of cross-industry pairs represents the number of industry pairs that are connected through board interlocks, and the number of cross-industry ties (board interlocks) represents the number of board interlock between firms in different industries. The analysis is conducted at two scales of industrial classification to control for the possibility that the 2-Digit industrial classification over-estimates industrial distinctiveness.13 To do so the analysis is also conducted at the level of divisions, which categorize firms into nine broad industrial categories.

No matter which level of industrial classification is used, results using various proxies for cross-industry bridging consistently show the two regions to have similar levels of bridging relations back in 1982, and these measures diverge over the period of economic divergence. In fact the LA regions had a greater number of cross-industry pairs and ties at both the 2-Digit

SIC level of analysis and at the division level back in 1982. By 1995 and even more so by 2010, the Bay Area had a greater number of cross-industry pairs and cross-industry ties than LA. In 2010, the Bay Area network had 30 cross-industry pairs compared to 22 in LA, and 52 versus 27 cross-industry ties across 2-Digit SIC industrial categories. While the number of cross-division pairs is comparable (albeit a little higher in LA throughout the period), which is expected given the broadness of this industrial classification, by 2010 the Bay Area network had more than double the number of board interlocks that connect firms across these broad industrial categories (43 compared to 19 in LA - see Table 5).

Table 5. Cross-industry pairs and ties.

\begin{tabular}{|c|c|c|c|c|}
\hline & \multicolumn{4}{|c|}{ Two-digit SIC } \\
\hline & \multicolumn{2}{|c|}{ Cross-industry pairs } & \multicolumn{2}{|c|}{ Cross-industry ties } \\
\hline & LA & Bay Area & LA & Bay Area \\
\hline 1982 & 65 & 57 & 94 & 86 \\
\hline 1995 & 31 & 40 & 52 & 68 \\
\hline \multirow[t]{4}{*}{2010} & 22 & 30 & 27 & 52 \\
\hline & \multicolumn{4}{|c|}{ SIC divisions } \\
\hline & \multicolumn{2}{|c|}{ Cross-division pairs } & \multicolumn{2}{|c|}{ Cross-division ties } \\
\hline & So Cal & SF Bay Area & So Cal & SF Bay Area \\
\hline 1982 & 19 & 14 & 77 & 69 \\
\hline 1995 & 13 & 11 & 41 & 52 \\
\hline 2010 & 11 & 8 & 19 & 43 \\
\hline
\end{tabular}

Source: Author's calculations using UCI-Net. 
In order to make sure that these cross-industry ties are not predominantly due to a very small number of highly connected industries, the analysis also compared the average number of cross-industry ties, as well as the maximum number of cross-industry ties exhibited by the most connected industry. Again results show the two networks to be very similar back in 1982, with identical average number of cross-industry ties (Mean Degree), and number of ties connecting the most connected industry to other industries (Table 6). The networks again diverge across these two measures over the period. By 2010, the average number of crossindustry ties in the Bay Area network is 5, compared to 1.5 in the LA network, and the most connected industry in the Bay Area dwarfs the most connected industry in LA, with 21 versus 5 cross-industry ties.

Table 6. Average number of cross-industry ties and most connected industry.

\begin{tabular}{lcccccc}
\hline & \multicolumn{2}{c}{1982} & \multicolumn{2}{c}{1995} & \multicolumn{2}{c}{2010} \\
\cline { 2 - 7 } & LA & Bay Area & LA & Bay Area & LA & Bay Area \\
\hline Mean degree & 5.7 & 5.7 & 3.7 & 5.2 & 1.5 & 5 \\
Maximum & 26 & 30 & 18 & 26 & 5 & 21 \\
\hline
\end{tabular}

Source: Authors' calculations.

In addition to the number of cross-industry pairs, ties, mean degree, and most connected industry, the analysis also compares the breadth of ties in the regional networks. In 1980, LA's industries were linked to a broader range of sectors, with 11 industries tied to five or more industries, while the Bay Area had eight. By 1995, however, LA had only seven industries that were connected to five or more other industries against 11 in the Bay Area. By 2010, Los Angeles had no industries connected to five or more other industries, and the Bay Area had four. Against a backdrop of declining inter-industry links, the Bay Area's network remains broader than that of LA.

In sum, from comparable starting points in 1982, the Los Angeles and Bay Area social networks under investigation have diverged over the study period. Over time the networks of corporate directors in the Bay Area maintain a high degree of social relations, and these social relations consistently cross-industrial boundaries. Despite the Los Angeles metro-region having a more diverse industrial structure, evident both in its overall economy and its largest corporations, its business leaders over time appear to become isolated from each other, both in relation to its recent past, and to its northern neighbour.

\section{Conclusion}

The research in this article reveals a divergence in the network structures of interlocking corporate boards of the largest firms in the Bay Area and Los Angeles metropolitan regions over the three decades of economic divergence, 1980 to 2010. Network analyses reveal that the two regional networks were remarkably similar back in the early 1980s in terms of industrial composition, connectivity and cross-industry bridging relations. Over the subsequent three decades, however, the Bay Area's network of corporate interlocks maintains its degree of overall connectivity, its degree of bridging relations across industrial boundaries, and by 2010 is characterized by a well-connected and centrally positioned BCO, the Bay Area Council. It 
does so against the odds given greater specialization and corporate concentration in fewer industries. The LA network, on the other hand, fragments substantially in terms of both overall connectivity and cross-industry relations, and by 2010 its most central BCO, the LA Chamber of Commerce, is much less connected and central than its Bay Area counterpart.

Over the divergence period the Bay Area was better able to combine and recombine its assets, people and organizations in response to new challenges and opportunities in an emerging 'new economy'. Our findings support the theory in economic sociology that this recombinatory process was enabled by a more connected and diverse social context, which generated a critical mass of entrepreneurial ventures and innovation. The industrial structure thus developed down a high-road economic trajectory, raising the region's per capita income by 2010 to levels higher than regions with comparable initial factor endowments. LA's industrial social structure, on the other hand, for whatever reasons beyond the scope of this article, became increasingly fragmented. Theory would hold that the region was thus less able to re-combine its assets, people and organizations in response to the changing economic context of globalization and technological change. As a result it was less able to steer its industrial structure down new high-waged economic trajectories due to its much lower level of innovation and entrepreneurship.

These findings however do not explain why the relational social structures of the Bay Area and Los Angeles regions diverged in the first instance, especially given their similarities back in 1980. Both regions faced the challenges and opportunities of the New Economy with a comparable industrial structure, human capital and level of technological sophistication. Indepth historical analysis in a recent book co-authored by Storper, Kemeny, Makarem and Osman (Storper et al., 2015) explores the roles of first-nature geography, inter-jurisdictional politics, perceptions and world views of business and political elites, corporate practices and attitudes, and civil-society dynamics in shaping the social context of the two regions. The network findings are a reflection of complex social, economic and political dynamics that have shaped the development of these two regions over the course of the 20th Century.

What the findings in this research do show is that the structure of social networks in the Bay Area and Los Angeles diverged over the period of economic divergence and did so in a way that is consistent with theory in the social capital and economic sociology literatures that social contexts. Irrespective of the causes behind this divergence in social structures, the research confirms an association between innovation and entrepreneurship in the face of economic challenges and opportunities on the one hand, and diverse and connected business networks on the other. This raises important implications for policy makers and BCOs about the strategic role they can play in encouraging bridging relations between influential actors from across diverse regional industrial communities.

Acknowledgements. I would like to extend my sincere gratitude to Prof. Michael Storper for his invaluable support, guidance and insights throughout my doctoral studies; the rest of the Haynes-Project team, Taner Osman and Tom Kemeny for their contributions and countless insights and advice over the years; and to my committee members, Chris Tilly, Susanna Hecht (at UCLA) and Manuel Pastor (at USC) for their time, guidance and support. I am also grateful to Brenda L Burk for her help and support accessing valuable resources at the Philanthropy Archives of Indianapolis University, and research assistant Mathew Stevenson for his diligent support in scanning and extracting archived material. I am also very grateful to the faculty of Urban Planning and Geography at UCLA for comments and advice during informal 
conversations and for the welcoming and intellectually stimulating community they provided during my doctoral studies, and to all esteemed interviewees who were kind enough to share their time and insights with me.

Declaration of Conflicting Interest. The author declared no potential conflicts of interest with respect to the research, authorship, and/or publication of this article.

\section{Notes:}

(1) The Bay Area region is composed of 10 counties: Alameda, Contra Costa, Marin, Napa, San Francisco, San Mateo, Santa Clara, Solano, Sonoma and Santa Cruz.

(2) The Los Angeles region is composed of 5 counties: Los Angeles, Riverside, Orange, San Bernardino and Ventura

(3) While differences in regional, county and city-level governance systems exist, research by Taner Osman in a recent book by Michael Storper, Tom Kemeny, Naji P. Makarem and Taner Osman titled "The rise and fall of regional economies: Lessons from Los Angeles and San Francisco" (Storper et al., 2015) concludes that these systems are either too weak or uncoordinated to explain the economic divergence of these two metropolitan regions.

(4) Analysis of median incomes reveals the same story of divergence between 1980 and 2010 (Makarem, 2013).

(15) A project of the Building Resilient Regions Network, funded by the John D and Catherine T MacArthur Foundation. Manuel Pastor, Justin Scoggins, T William Lester, Karen Chapple, Building Resilient Regions database [Machine-readable database]. Los Angeles, CA: The USC Program for Environmental and Regional Equity (PERE).

(5) For a much more detailed investigation of factors behind the divergence see Storper et al., 2015. The authors conclude that none of these factors can sufficiently explain the divergence, and moreover that the economic divergence is best explained by the distinct trajectories of the two regions' industrial structures and innovation capacities. Moreover their analysis shows that, consistent with the Balassa- Samuelson effect, the success of the Bay Area's innovative high-waged industries spillover into lower-waged sectors of the economy, raising the income of most workers compared to their equivalent counterparts in Los Angeles.

(6) Unfortunately the board members of most business-civic organizations in earlier periods were not available.

(7) Earliest available year with revenues ranked by State, which were manually ranked by our two regions using business address.

(8) Details of the rules used are available upon request.

(9) A component is a network of nodes connected to one another. A social structure can be composed of more than one component if actors form more than one component, i.e. there is more than one network of connected nodes in the overall social structure (John is connected to Bill and Sarah in one component, and Roger is connected to Stuart in a second component Thus forming a network composed of two components, with the largest component consisting of 3 connected actors).

(14) Borgatti S P, Everett M G, Freeman L C, 2002, Ucinet for Windows: Software for Social Network Analysis (Analytic Technologies, Harvard, MA)

(11) A random network is constructed by randomly selecting a given number of ties between the nodes in a network.

(12) The probability that a random tie between two firms crosses an industrial boundary is higher in LA because firms in the 2010 LA sample is distributed more evenly across a broader number of industries. 
(13) Firms categorized into distinct 2-Digit SIC codes might in fact be in different sub-sectors (the 2-Digit SIC codes) within the same broad industry.

\section{References}

Aghion P, Alesina A, Trebbi F, 2004, "Endogenous political institutions" Quarterly Journal of Economics 119 565-612

Aghion P, Howitt P, 1992, "A model of growth through creative destruction" Econometrica60 323-351

Allen M P, 1974, "The structure of interorganizational elite cooptation: interlocking corporate directorates" American Sociological Review 39 393-406

Bagnasco A, 1977, Tre Italie: la problematica territoriale dello sviluppo italiano Vol. 74 (Il mulino) pp 379-433

Bourdieu P, 1986, "The forms of capital", in Handbook of Theory and Research for the Sociology of Education Ed. J G Richardson (Greenwood, New York, NY) pp 81-93

Bowles S, Gintis H, 2002, "Social capital and community governance" Economic Journal $112419-436$

Brusco S, 1986, "Small firms and industrial districts: the experience of Italy", in New Firms and Regional Development in Europe Eds D Keeble, E Wever (Taylor \& Francis, London) pp 184-202

Buchanan J, Tullock G, 1962, The Calculus of Consent (University of Michigan Press, Ann Arbor)

Castilla E J, Hwang H, Granovetter E, Granovetter M, 2000, Social networks in Silicon Valley, in The Silicon Valley Edge: A Habitat for Innovation and Entrepreneurship Ed. C M Lee (Stanford University Press, Stanford, CA) pp 218-247

Cohen W M, Levinthal D A, 1990, "Absorptive capacity: a new perspective on learning and innovation" Administrative Science Quarterly 35(1) 128-152

Coleman J S, 1988, Social capital in the creation of human capital. American Journal of Sociology 94 95-120

Cooke P, Morgan K, 1994, "Growth regions under duress: renewal strategies in BadenWiirttemberg and Emilia-Romagna", in Globalization, Institutions and Regional Development in Europe Eds A Amin, N Thrift (Oxford University Press, Oxford) pp 91117

Davis G F, 1996, "The significance of board interlocks for corporate governance" Corporate Governance: An International Review 4(3) 154-159

Dooley P C, 1969, "The interlocking directorate" The American Economic Review 59(3) 314-323

Duranton G, Puga D, 2004, "Micro-foundations of urban agglomeration economies", in Handbook of Regional and Urban Economics, Vol.4 Eds J Henderson, J-F Thisse (Elsevier, Amsterdam) pp 2063-2117

Easterly W, 2001, The Elusive Quest for Growth (MIT Press, Cambridge, MA)

Easterly W, Levine R, 1997, “Africa's growth tragedy: politics and ethnic divisions" Quarterly Journal of Economics 112 1203-1250

Feldman M, Zoller T D, 2012, "Dealmakers in place: social capital connections in regional entrepreneurial economies" Regional Studies 46(1) 23-37

Feldman M P, 1999, "The new economics of innovation, spillovers and agglomeration: a review of empirical studies" Economics of Innovation and New Technology 8(1-2) 5-25

Feldman P M, 1994, The Geography of Innovation Volume 2 (Kluwer Academic Publishers, The Netherlands) 
Fukuyama F, 1999, "Social capital and civil society", paper presented at the International Monetary Fund Conference on Second Generation Reforms, Washington, DC

Glaeser E L, Scheinkman J, Shleifer A, 1995, "Economic growth in a cross-section of cities" Journal of Monetary Economics 36(1) 117-143

Granovetter M, 2005, "The impact of social structure on economic outcomes" Journal of Economic Perspectives 19(1) 33-50

Granovetter M S, 1985, "Economic action and social structure: the problem of embeddedness" American Journal of Sociology 91(3) 481-510

Grossman G M, Helpman E, 1991, Innovation and Growth in the Global Economy (MIT Press, Cambridge, MA)

Hallock K F, 1997, "Reciprocally interlocking boards of directors and executive compensation" Journal of Financial and Quantitative Analysis 32(03) 331-344

Jacobs J, 1969, The Death and Life of Great American Cities (Vintage Books, New York, $\mathrm{NY}$ )

Jaffe A B, 1986, “Technological opportunity and spillovers of R \& D: evidence from firms' patents, profits, and market value" The American Economic Review 76(5) 984-1001

Jaffe A B, Trajtenberg M, 1996, "Flows of knowledge from universities and federal labs: modelling the flow of patent citations over time and across institutional and geographic boundaries" Proceedings of the National Academy of Sciences 93(23) 12671-12677

Jaffe A B, Trajtenberg M, Henderson R, 1993, "Geographic localization of knowledge spillovers as evidenced by patent citations" The Quarterly Journal of Economics 108(3) $577-598$

Jaffe A, Trajtenberg M, 1999, "International knowledge flows: Evidence from patent citations" Economics of Innovation and New Technology 8(1-2) 105-136

Jones C, 2004, "Growth and ideas", Working paper 10767, National Bureau of Economic Research, Cambridge, MA

Kenney M, Florida R, 2000, "Venture capital in Silicon Valley: fuelling new firm formation" in Understanding Silicon Valley: The Anatomy of an Entrepreneurial Region Ed. M Kenney (Stanford University Press, Stanford, CA) pp 98-123

Kenney M, von Burg U, 2001, "Paths and regions: the creation and growth of Silicon Valley" Organization Science 8 109-125

Kristensen P H, 1992, "Industrial districts in West Jutland, Denmark", in Industrial Districts and Local Economic Regeneration Ed. F Pyke, W Sengenberger (International Institute for Labour Studies, International Labour Organization, Geneva) pp 122-173

Levine J H, 1977, "The network of corporate interlocks in the United States: an overview", keynote paper for the American Sociological Association Annual Meeting, Chicago

Lucas R E, 1988, "On the mechanics of economic development" Journal of Monetary Economics 22 3-42

Makarem N P, 2013, "Perceptions, relations and regional economic development: a case study of the Bay Area and Southern California", UCLA electronic theses and dissertations, eScholarship, Los Angeles, CA

Marshall A, 1890, Principles of Economics (Macmillan, London)

Mintz B A, Schwartz M, 1985 The Power Structure of American Business (University of Chicago Press, Chicago)

Mizruchi M S, 1996, "What do interlocks do? An analysis, critique, and assessment of research on interlocking directorates" Annual Review of Sociology 22(1) 271-298

Mizruchi M S, Stearns L B, 1988, "A longitudinal study of the formation of interlocking directorates" Administrative Science Quarterly 33(2) 194-210

Myint Y M, Vyakarnam S, New M J, 2005, "The effect of social capital in new venture creation: the Cambridge high technology cluster" Strategic Change 14 169-171 
North D C, 1981, Structure and Change in Economic History (W. W. Norton, New York, $\mathrm{NY}$ )

North D C, 1990, Institutions, Institutional Change and Economic Performance (Cambridge University Press, Cambridge, UK)

North D C, 2005, Understanding the Process of Economic Change (Princeton University Press, Princeton, NJ)

Olson M, 1965, The Logic of Collective Action (Harvard University Press, Cambridge, MA)

Owen-Smith J, Powell W W, 2008, "Networks and institutions" in The Sage Handbook of Organizational Institutionalism Eds R Greenwood, C Oliver, R Suddaby, K SahlinAndersson (Sage, London, UK) pp 596-623

Patel P, Pavitt K, 1991, "Large firms in the production of the world's technology: an important case of "non- globalisation'" Journal of International Business Studies 22(1) 121

Piore M J, Sabel C F, 1984, The Second Industrial Divide: Possibilities for Prosperity (Basic Books, New York, NY)

Pollock T G, Porac J F, Wade J B, 2004, "Constructing deal networks: brokers as network 'architects' in the U.S. IPO market and other examples" The Academy of Management Review 29 50-72

Powell W W, Packalen K A, Whittington K, 2010, "Organizational and institutional genesis: the emergence of high-tech clusters in the life sciences", in The Emergence of Organizations and Markets Eds J F Padgett, W W Powell (Princeton University Press, Princeton, NJ)

Powell W W, Packalen K, Whittington K, 2012a, "Organizational and institutional genesis: the emergence of high-tech clusters in the life sciences", in The Emergence of Organizations and Markets Eds J F Padgett, W W Powell (Princeton University Press, Princeton, NJ) pp 275-378

Powell W W, Packalen K, Whittington K, 2012b, 'Chance, Nécessité, et Naïveté' in The Emergence of Organizations and Markets Eds J F Padgett, W W Powell (Princeton University Press, Princeton, NJ)

Powell W W, Sandholtz K W, 2012, "Amphibious entrepreneurs and the emergence of organizational forms" Strategic Entrepreneurship Journal 6(2) 94-115

Powell W W, White D R, Koput K W, Owen-Smith J, 2005, "Network dynamics and field evolution: the growth of interorganizational collaboration in the life sciences" American Journal of Sociology 110(4) 1132-1205

Putnam R D, 2000, Bowling Alone: The Collapse and Revival of American Community (Simon \& Schuster, Cambridge, MA)

Putnam R D, Leonardi R, 1993, Making Democracy Work: Civic Traditions in Modern Italy (Princeton University Press, Princeton, NJ)

Rodríguez-Pose A, 2013, “Do institutions matter for regional development?” Regional Studies 47(7) 1034-1047

Rodriguez-Pose A, Storper M, 2006, "Better rules or stronger communities? On the social foundation of institutional change and its economic effects" Economic Geography 82(1) $1-25$

Romer P M, 1986, "Increasing returns and long run growth" Journal of Political Economy 94 1002-1037

Romer P M, 1987, "Growth based on increasing returns due to specialization" American Economic Review 77 56-62

Romer P M, 1990, "Endogenous technological change" Journal of Political Economy 98(5) S71-S102 
Romer P M, 1993, "Idea gaps and object gaps in economic development" Journal of Monetary Economics 32(3) 543-573

Safford S, 2004, "Why the garden club couldn't save Youngstown: civic infrastructure and mobilization in economic crises", MIT working paper series, IPC-04-002 pp 41-60

Saxenian A, 1983, "The urban contradictions of Silicon Valley: regional growth and the restructuring of the semiconductor industry" International Journal of Urban and Regional Research7(2) 237-262

Saxenian A, 1990, "Regional networks and the resurgence of Silicon Valley" California Management Review 33(1) 89-112

Saxenian A, 1996, Regional Advantage: Culture and Competition in Silicon Valley and Route 128 (First Harvard University Press, Harvard, MA)

Scott A, 1988, Metropolis: From the division of labour to urban form (University of California Press)

Storper M, 1992, "The limits to globalization: Technology districts and international trade" Economic Geography 60-93.

Sonn J W, Storper M, 2008, "The increasing importance of geographical proximity in knowledge production: an analysis of US patent citations, 1975-1997" Environment and Planning A 40(5) 1020.

Storper M, 1997, The Regional World: Territorial Development in a Global Economy (Guilford Press, New York, NY)

Storper M, Harrison B, 1991, "Flexibility, hierarchy and regional development: the changing structure of industrial production systems and their forms of governance in the 1990s" Research Policy 20(5) 407-422

Storper M, Kemeny T, Makarem N P, Osman T, (2015), The Rise and Fall of Urban Economies: San Francisco and Los Angeles Since 1970 (Stanford University Press, Stanford, CA)

Storper M, Scott A J, 1992, Pathways to Industrialization and Regional Development (Rutledge, London, UK) pp 15-47

Sturgeon T J, 2000, "How Silicon Valley came to be", in Understanding Silicon Valley: The Anatomy of an Entrepreneurial Region Eds M Kenney, R Florida (Stanford University Press, Stanford, CA)

Suchman M C, 2000, "Dealmakers and counsellors: law firms as intermediaries in the development of Silicon Valley", in Understanding Silicon Valley: The Anatomy of an Entrepreneurial Region Eds M Kenney, R Florida (Stanford University Press, Stanford, CA) pp 71-97

Thomas W F, Ong P, 2002, "Barriers to rehiring of displaced workers: a study of aerospace engineers in California" Economic Development Quarterly 16(2) 167-178

Triglia C, 1992, "Italian districts: neither myth nor interlude", in Industrial Districts and Local Economic Regeneration Eds F Pyke, W Sengenberger (International Institute of Labour Studies, Geneva) pp 33-47

Turner F, 2010, From Counterculture to Cyberculture: Stewart Brand, the Whole Earth Network, and the Rise of Digital Utopianism (University of Chicago Press, Chicago)

Wade R, 1987, "The management of common property resources: finding a cooperative solution" World Bank Research Observer 2 219-234

Winch G M, Courtney R, 2007, "The organization of innovation brokers: an international review" Technology Analysis \& Strategic Management 19 747-763 


\section{APPENDIX:}

Appendix 1. Descriptive statistics for Los Angeles, the Bay Area and the US average - for variables used as controls in models 1 and 2 .

\begin{tabular}{lcccccc}
\hline Variables in model 1 & LA & Bay Area & US Mean & $\begin{array}{c}\text { Standard } \\
\text { error }\end{array}$ & \multicolumn{2}{c}{$\begin{array}{c}\text { Confidence } \\
\text { interval }\end{array}$} \\
\hline PCInc growth 1980-2010 & 2.29 & 3.078 & 2.60 & 0.03 & 2.55 & 2.66 \\
Initial income (1980) & 8,360 & 9,312 & 7,086 & 72.92 & 6,942 & 7,230 \\
Log Pop 1980 & 16.26 & 15.50 & 13.20 & 0.08 & 13.05 & 13.36 \\
Share income on rent (1980) & 26.52 & 25.14 & 24.51 & 0.16 & 24.19 & 24.84 \\
\%BA> (1980) & 0.18 & 0.25 & 0.16 & 0.00 & 0.15 & 0.17 \\
\%HS<(1980) & 0.59 & 0.52 & 0.68 & 0.01 & 0.67 & 0.69 \\
\%Hispanic & 0.24 & 0.12 & 0.06 & 0.01 & 0.04 & 0.08 \\
\% Manufacturing & 0.21 & 0.16 & 0.18 & 0.01 & 0.17 & 0.20 \\
\% FIRE & 0.09 & 0.10 & 0.07 & 0.00 & 0.07 & 0.08 \\
\#Patents/Capita & 35.64 & 48.05 & 23.74 & 1.30 & 21.18 & 26.30 \\
\hline Variables added in model 2 & & & & & & \\
\hline Pop Growth 1980-2010 & 0.53 & 0.35 & 0.47 & 0.04 & 0.39 & 0.54 \\
\%Hispanic 1990 & 0.32 & 0.15 & 0.08 & 0.01 & 0.06 & 0.10 \\
\%Hispanic 2000 & 0.40 & 0.20 & 0.11 & 0.01 & 0.08 & 0.13 \\
\%Hispanic 2010 & 0.44 & 0.22 & 0.13 & 0.01 & 0.10 & 0.15 \\
\hline
\end{tabular}

Source: Author's calculations using BRR data. 
Appendix 2. Regression results for models 1 and 2, and relative performance for LA and the Bay Area.

\begin{tabular}{lcc}
\hline & Model 1 & Model 2 \\
\hline Number of observations & 165 & 165 \\
R2 & 0.51 & 0.57 \\
Adjusted R2 & 0.48 & 0.53 \\
Initial income (1980) & $-.000278^{*}$ & $-.000248^{*}$ \\
Log Pop 1980 & $.11589^{*}$ & $.13057^{*}$ \\
Share income on rent (1980) & .017 & .012 \\
\%BA> (1980) & $6.65^{*}$ & $5.97^{*}$ \\
\%HS<(1980) & $2.72^{*}$ & $2.24^{*}$ \\
\%Hispanic & $-1.30^{*}$ & -2.24 \\
\% Manufacturing & -.012 & .15 \\
\% FIRE & $6.97 *$ & $4.65 *$ \\
\#Patents/Capita & .0009 & .0006 \\
Pop Growth 1980-2010 & - & $.249^{*}$ \\
\%Hispanic 1990 & - & 4.86 \\
\%Hispanic 2000 & - & -4.47 \\
\%Hispanic 2010 & & .66 \\
Constant & -.74 & -.48 \\
2010 per capita income's percentage above or below prediction & \\
Bay Area & $22 \%$ & $22 \%$ \\
Los Angeles & $-7 \%$ & $-7 \%$ \\
\hline
\end{tabular}

Source: Author's calculations using OLS regression.

*Significant to the $1 \%$ level. 